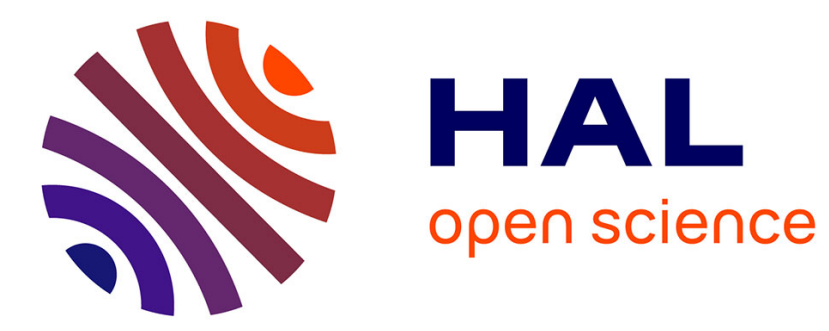

\title{
Characterisation of the biodegradability of post-treated digestates via the chemical accessibility and complexity of organic matter
}

Géraldine Maynaud, Céline Druilhe, Mylène Daumoin, Julie Jimenez, Dominique Steyer, Michel Torrijos, Anne-Marie Pourcher, Nathalie Wéry

\section{To cite this version:}

Géraldine Maynaud, Céline Druilhe, Mylène Daumoin, Julie Jimenez, Dominique Steyer, et al.. Characterisation of the biodegradability of post-treated digestates via the chemical accessibility and complexity of organic matter. Bioresource Technology, 2017, 213, pp.65-74. 10.1016/j.biortech.2017.01.057 . hal-01606007

\section{HAL Id: hal-01606007 https://hal.science/hal-01606007}

Submitted on 26 May 2020

HAL is a multi-disciplinary open access archive for the deposit and dissemination of scientific research documents, whether they are published or not. The documents may come from teaching and research institutions in France or abroad, or from public or private research centers.
L'archive ouverte pluridisciplinaire HAL, est destinée au dépôt et à la diffusion de documents scientifiques de niveau recherche, publiés ou non, émanant des établissements d'enseignement et de recherche français ou étrangers, des laboratoires publics ou privés. 


\section{Accepted Manuscript}

Characterisation of the biodegradability of post-treated digestates via the chemical accessibility and complexity of organic matter

Géraldine Maynaud, Céline Druilhe, Mylène Daumoin, Julie Jimenez, Dominique Patureau, Michel Torrijos, Anne-Marie Pourcher, Nathalie Wéry

PII: S0960-8524(17)30094-9

DOI: http://dx.doi.org/10.1016/j.biortech.2017.01.057

Reference: BITE 17552

To appear in:

Bioresource Technology

Received Date:

2 December 2016

Revised Date: 24 January 2017

Accepted Date: 27 January 2017

Please cite this article as: Maynaud, G., Druilhe, C., Daumoin, M., Jimenez, J., Patureau, D., Torrijos, M., Pourcher, A-M., Wéry, N., Characterisation of the biodegradability of post-treated digestates via the chemical accessibility and complexity of organic matter, Bioresource Technology (2017), doi: http://dx.doi.org/10.1016/j.biortech. 2017.01.057

This is a PDF file of an unedited manuscript that has been accepted for publication. As a service to our customers we are providing this early version of the manuscript. The manuscript will undergo copyediting, typesetting, and review of the resulting proof before it is published in its final form. Please note that during the production process errors may be discovered which could affect the content, and all legal disclaimers that apply to the journal pertain. 


\title{
Characterisation of the biodegradability of post-treated digestates via the chemical accessibility and complexity of organic matter
}

Géraldine Maynaud $^{\mathrm{a}}$, Céline Druilhe ${ }^{\mathrm{b}, \mathrm{c}}$, Mylène Daumoin ${ }^{\mathrm{b}, \mathrm{c}}$, Julie Jimenez ${ }^{\mathrm{a}}$, Dominique Patureau $^{\mathrm{a}}$, Michel Torrijos ${ }^{\mathrm{a}}$, Anne-Marie Pourcher ${ }^{\mathrm{b}, \mathrm{c}}$, and Nathalie Wéry ${ }^{\mathrm{a} *}$

${ }^{a}$ LBE, INRA, 102 Avenue des Etangs, Narbonne, F-11100, France

${ }^{\mathrm{b}}$ Irstea, UR OPAALE, 17 avenue de Cucillé, CS64427, Rennes, F-35044, France

${ }^{c}$ Université Bretagne Loire, France

*Corresponding author. Tel: +33 4684251 86; E-mail address: nathalie.wery@inra.fr

\begin{abstract}
The stability of digestate organic matter is a key parameter for its use in agriculture.

Here, the organic matter stability was compared between 14 post-treated digestates and the relationship between organic matter complexity and biodegradability was highlighted. Respirometric activity and $\mathrm{CH}_{4}$ yields in batch tests showed a positive linear correlation between both types of biodegradability $\left(\mathrm{R}^{2}=0.8\right)$. The accessibility and complexity of organic matter were assessed using chemical extractions combined with fluorescence spectroscopy, and biodegradability was mostly anti-correlated with complexity of organic matter. Post-treatments presented a significant effect on the biodegradability and complexity of organic matter. Biodegradability was low for composted digestates which comprised slowly accessible complex molecules. Inversely, solid fractions obtained after phase separation contained a substantial part of remaining biodegradable organic matter with a significant easily accessible fraction comprising
\end{abstract}


simpler molecules. Understanding the effect of post-treatment on the biodegradability of digestates should help to optimize their valorization.

Keywords: digestate; biodegradability; complexity; anaerobic digestion; respirometry

\section{Abbreviations}

AD: Anaerobic digestion

$\mathrm{AT}_{4}$ : Cumulative oxygen uptake in four days $\left(\mathrm{gO}_{2} \mathrm{~kg}^{-1} \mathrm{VS}\right)$

BDaero: Aerobic biodegradability (\% CODtot)

BDana: Anaerobic biodegradability (\% CODtot)

BMP: Biomethane potential $\left(\mathrm{NLCH}_{4} \mathrm{~kg}^{-1} \mathrm{VS}\right)$

BOD: Biological oxygen demand $\left(\mathrm{gO}_{2} \mathrm{~kg}^{-1} \mathrm{VS}\right)$

$\mathrm{CO}_{2}$ : Carbon dioxide

CODtot: Total chemical oxygen demand $\left(\mathrm{gO}_{2} \mathrm{~kg}^{-1} \mathrm{VS}\right)$

DOM: dissolved organic matter

$\mathrm{DRI}_{24}$ : Average $\mathrm{O}_{2}$ uptake rate in the $24 \mathrm{~h}$ of maximum activity $\left(\mathrm{mgO}_{2} \mathrm{~h}^{-1} \mathrm{~kg}^{-1} \mathrm{VS}\right)$

MB: easily biodegradable fraction (\%BDaero)

MH: slowly biodegradable fraction (\%BDaero)

MSW: Municipal solid waste

NEOM: Non extractable organic matter (\% CODtot)

$\mathrm{O}_{2}$ : Oxygen

OFMSW: Organic fraction of municipal solid waste

OM: Organic matter

OUR: Oxygen uptake rate $\left(\mathrm{mmO}_{2} \mathrm{~h}^{-1} \mathrm{~kg}^{-1} \mathrm{VS}\right)$ 
PEOM: Poorly extractable organic matter (\% CODtot)

REOM: Readily extractable organic matter (\% CODtot)

RT: Retention time

SEOM: Slowly extractable organic matter (\% CODtot)

SPOM: Soluble extractable fraction from particular extractable organic matter (\%

CODtot)

TS: Total solid

VS: Volatile solid

\section{Introduction}

Anaerobic digestion (AD) is a biological treatment that converts organic waste into methane $\left(\mathrm{CH}_{4}\right)$. It can thus produce energy, while the digestate is regarded as a potential organic fertilizer. The digestate is a fully fermented nutrient-rich material which can ideally replace inorganic fertilizer (Tambone et al., 2010). Many studies focus on the optimization of $\mathrm{CH}_{4}$ production from organic waste but rarely on the assessment of the agronomic value of digestate and its valorisation through land application (Teglia et al., 2010). At times, when digestate is not fully stabilized, it can present residual biodegradability and contain complex organic elements such as lignocellulosic compounds which the digestion process cannot degrade (Bayard et al., 2015).

Consequently, post-treatments such as solid-liquid separation, drying or composting, are generally recommended before land application and the fertilizer produced should also fulfil current standards, i.e. efficiency and safety (Teglia et al., 2011).

To be used as an organic fertilizer, stability or biodegradability of a digestate has to be fully assessed prior to land application. The biodegradability of organic residues 
can be evaluated using (i) biological methods including aerobic respirometric tests and anaerobic test methods (Binner and Zach, 1999; Wagland et al., 2009) and (ii) nonbiological methods including dry matter, organic matter (OM) and total organic carbon content (Godley et al., 2004). The use of the biomethane potential test (BMP) aims at assessing the biogas potential of both organic waste and digestate. It is the most common method applied for measuring the anaerobic biodegradability of organic residues (Schievano et al., 2008). However, the BMP test protocol can vary from one laboratory to another (Raposo et al., 2011) thus leading to large discrepancies. It is also a time-consuming method ( $>30$ days). For these reasons, alternative approaches such as respirometric tests have been considered (Cossu and Raga, 2008; Scaglia et al., 2010). These aerobic methods are based on the oxygen $\left(\mathrm{O}_{2}\right)$ measurement uptake or carbon dioxide $\left(\mathrm{CO}_{2}\right)$ production which are related to $\mathrm{OM}$ biodegradation under controlled conditions. As organic residues can either be directly applied on land or stored prior to their application, they can be exposed to both aerobic and anaerobic environments. An assessment of their biodegradability under aerobic and anaerobic conditions thus provides complementary information on their characteristics. Furthermore, correlations between aerobic and anaerobic tests have been reported by several authors, especially for organic waste before its biological treatment, such as $\mathrm{AD}$ processes or composting (Cossu and Raga, 2008; Ponsá et al., 2008; Barrena et al., 2009; Bohm et al., 2010; Liu et al., 2015). However, information is scarce concerning such correlations on digestates.

The objectives of this study are (i) to investigate the biodegradability under both anaerobic and aerobic conditions of 14 post-treated digestates (seven composted or dried solid fractions of digestate and seven solid fractions of digestate obtained after 
liquid-solid separation) and (ii) to characterize their OM in order to better assess the impact of post-treatments on their characteristics and stability. In this view, a recent method developed to characterize both the accessibility and complexity of organic wastes (Jimenez et al., 2015) has been applied. This method combines successive chemical fractionations to 3D fluorescence spectroscopy. The final goal was correlating biodegradability and OM characterization and describing the effect of post-treatment on the digestate stability. This could help to define better strategies for agricultural re-use of these organic residues.

\section{Material and methods}

\subsection{Sampling of digestates}

Fourteen digestates were sampled from 13 AD sites in France: 7 solid fractions of digestate (SL1S, SL2S, A1S, T1S, T2S, T3S, T4S) obtained following solid-liquid phase separation, 1 dried and composted solid fraction of digestate (A2D) and 6 composted solid fractions of digestate (A3C, A4C, SL1C, O1C, O2C, M1C). The AD sites treated various types of waste, including agricultural waste, sewage sludge from a wastewater treatment plant (WWTP), municipal solid waste (MSW), the organic fraction of MSW (OFMSW), food processing waste (FPW), all according to different digestion processes (wet or dry, mesophilic or thermophilic). The designation of the digestates and their origins are presented in Table 1. All of the samples collected (about $50 \mathrm{~kg}$ each) were homogenized for further analyses.

\subsection{Physico-chemical characterisation of digestates}


Representative aliquots of digestate (about $2 \mathrm{~kg}$ ) were used to perform all the analytical tests. For each sample, the total solid (TS) content was measured by drying $100 \mathrm{~g}$ of sample at $105^{\circ} \mathrm{C}$ for $48 \mathrm{~h}$. The volatile solid (VS) content was measured after calcination of this dried sample at $550{ }^{\circ} \mathrm{C}$ for $3 \mathrm{~h}$. Prior to total chemical oxygen demand (CODtot) measurements, the dried sample was ground to a particle size of 500 $\mu \mathrm{m}$. Then, CODtot was determined by titration after digesting $1 \mathrm{~g}$ of TS with $\mathrm{H}_{2} \mathrm{SO}_{4}$ and $\mathrm{K}_{2} \mathrm{Cr}_{2} \mathrm{O}_{7}$ in accordance with the AFNOR standard NF T90-101. CODtot results were expressed in $\mathrm{gO}_{2} \mathrm{~kg}^{-1} \mathrm{VS}$. All measurements were performed in triplicate.

\subsection{Residual biodegradability assays}

\subsubsection{Aerobic biodegradability assay (BDaero)}

The aerobic biodegradability was measured on fresh digestates (between 2 and $4 \mathrm{~kg}$ according to the bulk density) using a dynamic respirometric method (Berthe et al., 2007). The respirometric device consisted of $10 \mathrm{~L}$ hermetically sealed stainless steel cells. These were filled with the studied substrates mixed with plastic Pall rings acting as inert bulking agent. Each cell was maintained at $40{ }^{\circ} \mathrm{C}$ by means of a water bath and was supplied with a continuous air flow rate of $70 \mathrm{~L} \mathrm{~h}^{-1}$. The incoming air was preheated to the water bath temperature while the aeration system also included a rapid recirculation of part of the exhaust air $\left(360 \mathrm{~L} \mathrm{~h}^{-1}\right)$, thus ensuring homogeneous conditions throughout the substrate. In order to measure the $\mathrm{O}_{2}$ uptake rate (OUR) during the respirometric experiment, the oxygen concentrations of the inlet and outlet gases were monitored every 2 min using a paramagnetic analyser (Magnos 206, ABB, Zurich, Switzerland). The respirometric test was finally halted when the $\mathrm{O}_{2}$ uptake rate fell to a low and stable value. 
The biological oxygen demand (BOD) of the digestate corresponded to the cumulative $\mathrm{O}_{2}$ uptake during the test. Two classical aerobic indices were also calculated for each substrate: $\mathrm{AT}_{4}$ related to the cumulative $\mathrm{O}_{2}$ uptake in four days and $\mathrm{DRI}_{24}$ related to the average OUR in the $24 \mathrm{~h}$ of maximum activity (Ponsa et al., 2010). Moreover, the aerobic biodegradability (BDaero) could be expressed as the ratio between BOD and CODtot, according to Equation 1 (Liu et al., 2015).

BDaero $(\%$ CODtot $)=\left(\mathrm{BOD}\left(\mathrm{gO}_{2} \mathrm{~kg}^{-1} \mathrm{VS}\right) \times 100\right) / \operatorname{CODtot}\left(\mathrm{gO}_{2} \mathrm{~kg}^{-1} \mathrm{VS}\right)(1)$ A conceptual approach of typical OUR profiles has been described by Trémier et al. (2005): firstly (i) a rise to a peak value, OURmax, associated with the biodegradation of the easily biodegradable $\mathrm{OM}(\mathrm{MB})$ and biomass growth, secondly (ii) a break in the exponential growth and OUR decrease assumed to correspond to the biodegradation of the slowly biodegradable $\mathrm{OM}(\mathrm{MH})$ that has to be be hydrolysed before biological consumption, and thirdly (iii) the stabilization of OUR at a low and constant value associated with the disappearance of all biodegradable $\mathrm{OM}$ and the endogenous respiration of the biomass. On the basis of these previous assumptions, a simplified estimation of $\mathrm{MB}$ and $\mathrm{MH}$ could be carried out: the $\mathrm{MB}$ value represented the cumulative $\mathrm{O}_{2}$ consumption during the rising phase, until OURmax, while the $\mathrm{MH}$ value characterised the cumulative $\mathrm{O}_{2}$ uptake during the decrease phase, from OURmax to endogenous respiration. During this study, different OUR profiles were obtained: typical profiles with a single OUR peak, atypical profiles with two or three $\mathrm{O}_{2}$ uptake peaks. A simplified estimation of $\mathrm{MB}$ and $\mathrm{MH}$ was then performed for each separated peak: the MB1, MB2 and MB3 values represented the cumulative $\mathrm{O}_{2}$ consumption during the rising phase of the first, second and third peak respectively, and the MHi values ( $\mathrm{i}=1,2$ or 3 ) represented the cumulative $\mathrm{O}_{2}$ consumption during the decreasing 
phase of the first, second and third peak, respectively. Following the previously described calculations, $\mathrm{MBi}$ and $\mathrm{MHi}$ were expressed in \%BDaero.

\subsubsection{Anaerobic biodegradability assay (BDana)}

An anaerobic batch test was used to quantify the residual $\mathrm{CH}_{4}$ production in digestate.

This was measured on fresh digestate without inoculation for 40 days using the following protocol: $200 \mathrm{~g}$ of fresh digestate were suspended in $200 \mathrm{~mL}$ of sodium bicarbonate solution $\left(2.5 \mathrm{~g} \mathrm{~L}^{-1}\right)$ in $500 \mathrm{~mL}$ flasks. To ensure anaerobic conditions, the solution in flask was flushed with $\mathrm{N}_{2}$ for a few seconds. The flasks were sealed with gas-tight rubber stoppers and aluminium seals and incubated at $37{ }^{\circ} \mathrm{C}$ for 40 days in the dark and under a constant shaking. Each digestate was tested in duplicate. Biogas production and gas composition were estimated twice a week using a water displacement method and gas chromatography (Perkin Elmer Clarus®580), respectively. The $\mathrm{CH}_{4}$ yield was calculated using the experimental results and expressed in $\mathrm{NL} \mathrm{CH}_{4} \mathrm{~kg}^{-1}$ of $\mathrm{VS}$ under standard temperature and pressure conditions $\left(0{ }^{\circ} \mathrm{C}\right.$ and $1013 \mathrm{hPa})$.

Anaerobic biodegradability (BDana) was expressed as the ratio between the mean of $\mathrm{CH}_{4}$ yield and CODtot of the studied digestate, in accordance with the Equation 2 of Liu et al. (2015).

BDana $(\%$ CODtot $)=\left(\mathrm{CH}_{4}\right.$ yield $\left.\left(\mathrm{NL} \mathrm{CH}_{4} \mathrm{~kg}^{-1} \mathrm{VS}\right) \times 100\right) /\left(0.35 \times \operatorname{CODtot}\left(\mathrm{gO}_{2} \mathrm{~kg}^{-1} \mathrm{VS}\right)\right)$ (2)

Due to the low frequency of $\mathrm{CH}_{4}$ measurements (twice a week), the kinetic curves of the anaerobic batch tests were not analysed. Only the cumulative $\mathrm{CH}_{4}$ production at the end of the experiment was taken into account. 


\subsection{Organic matter characterisation}

\subsubsection{Chemical sequential extractions}

Organic matter was characterised according to Jimenez et al. (2015). Firstly, the sample was dried and grinded to $1 \mathrm{~mm}$ particle size, and the following sequential extractions were performed on $0.5 \mathrm{~g}$ of dried sample. Four fractions of decreasing accessibility were then obtained: (i) soluble extractible OM (SPOM) produced after four sequential extractions (30 $\mathrm{mL}$ of $\mathrm{CaCl}_{2}$ solution $10 \mathrm{mM}$ ) of the remaining pellet for $15 \mathrm{~min}$ at 30 ${ }^{\circ} \mathrm{C}$ and $300 \mathrm{rpm}$, (ii) readily extractible OM (REOM) produced after four sequential saline basic extractions ( $30 \mathrm{~mL}$ of $\mathrm{NaCl}$ and $\mathrm{NaOH} 10 \mathrm{mM}$ ) of the remaining pellet for $15 \mathrm{~min}$ at $30{ }^{\circ} \mathrm{C}$ and $300 \mathrm{rpm}$, (iii) slowly extractible OM (SEOM) produced after four sequential strong basic extractions $(30 \mathrm{~mL}$ of $\mathrm{NaOH} 0.1 \mathrm{M}$ ) of the remaining pellet for 4 $\mathrm{h}$ at $30{ }^{\circ} \mathrm{C}$ and $300 \mathrm{rpm}$, (iv) poorly extractible OM (PEOM) produced after two sequential acid extractions ( $25 \mathrm{~mL}$ of $\mathrm{H}_{2} \mathrm{SO}_{4} 72 \%$ (w:w)) of the remaining pellet for $3 \mathrm{~h}$ at $30{ }^{\circ} \mathrm{C}$ and $300 \mathrm{rpm}$. Finally, the non-extractible $\mathrm{OM}(\mathrm{NEOM})$ was calculated by subtracting the total OM extracted from the sample from the initial OM. At each step, the solubilised OM was recovered by centrifugation $\left(18600 \mathrm{~g}\right.$ at $4{ }^{\circ} \mathrm{C}$ for $\left.20 \mathrm{~min}\right)$ and filtered at $0.45 \mu \mathrm{m}$.

The chemical oxygen demand (COD) of total residues and extracts was measured in accordance with the standard ISO 15705:2002 in order to characterise the OM content of each fraction. Results are expressed as \% CODtot.

\subsubsection{Fluorescence spectroscopy analysis}


Similar to the procedure developed by Jimenez et al. (2014 and 2015), 3D fluorescence spectroscopy was applied to the extracted fractions, from which OM complexity could be quantified. The fluorescence spectrometer used was a Perkin Elmer LS55. Excitation wavelengths varied from 200 to $600 \mathrm{~nm}$ with $10 \mathrm{~nm}$ increments. According to Jimenez et al. (2014) and Muller et al. (2014), the spectra were decomposed into seven zones corresponding to biochemical fluorescence family-types. The proportion of fluorescence in a given zone " $i$ " $\mathrm{P}_{\mathrm{f}}(\mathrm{i})$ was calculated from the fluorescence zone volumes $\mathrm{V}_{\mathrm{f}}(\mathrm{i})$ according to Equations 3 and 4. An example of spectra decomposed into seven fluorescence zones is presented in the Supplementary figure 1.

$V_{\mathrm{f}}(\mathrm{i})\left(\mathrm{UA} \mathrm{mg} \mathrm{COD} \mathrm{L}^{-1}\right)=\frac{\mathrm{V}_{\mathrm{f}}(\mathrm{i})}{\operatorname{COD}_{\text {sample }}} \times 1 / \frac{\mathrm{S}(\mathrm{i})}{\sum_{\mathrm{i}=1}^{7} \mathrm{~S}(\mathrm{i})}$

$P_{\mathrm{f}}(\mathrm{i})(\%)=\frac{\mathrm{V}_{\mathrm{f}}(\mathrm{i})}{\sum_{\mathrm{i}=1}^{7} \mathrm{~V}_{\mathrm{f}}(\mathrm{i})} \times 100(4)$

Where:

$\mathrm{V}_{\mathrm{f}}(\mathrm{i})$ (U.A. $\mathrm{mg} \mathrm{COD} \mathrm{L}^{-1}$ ): the raw volume of the zone $\mathrm{i}$,

$\mathrm{COD}_{\text {sample }}\left(\mathrm{mg} \mathrm{L}^{-1}\right)$ : the COD concentration of the sample,

S(i) $\left(\mathrm{nm}^{2}\right)$ : the area of a zone i,

$P_{f}(i)(\%)$ : the fluorescence proportion of a zone $i$.

\subsection{Statistical analysis}

Correlations between the $\mathrm{CH}_{4}$ yield and each of the parameters obtained from respirometry (BOD, $\mathrm{AT}_{4}$ and $\left.\mathrm{DRI}_{24}\right)$, and between anaerobic (BDana) and aerobic (BDaero) biodegradabilities were investigated using linear regression evaluation. The analytical data were processed using principal component analysis (PCA) to identify multiple correlations between variables including BDana, BDaero, MBi and MHi (i=1, 
2 or 3), the complexity related to fluorescence and the \%CODtot of extracted OM fractions and NEOM fraction. A Pearson correlation matrix was performed in order to test for correlations between anaerobic and aerobic biodegradabilities and \%CODtot of each extracted fraction. Statistical analysis was performed using the Rcmdr package of R-Software (R Foundation for Statistical Computing, Vienna, Austria).

\section{Results and discussion}

\subsection{Characterization of digestates}

Table 2 summarizes the physico-chemical and biological properties of digestates. Anaerobic and aerobic biodegradabilities were calculated with the $\mathrm{CH}_{4}$ yield and BOD, respectively, and with respect to CODtot content of digestate.

The TS content ranged between 40.9-74.6\% for dried or composted solid digestate fractions, the highest value being observed for the dried sample A2D. In solid digestate fractions the TS content varied between 22.3-26.4 \%. The VS ranged between 39.3-86.5 $\%$ TS and the CODtot between $1245-1696 \mathrm{gO}_{2} \mathrm{~kg}^{-1} \mathrm{VS}$ in all the digestates, without any notable differences related to the applied post-treatment.

The calculated aerobic and anaerobic biodegradabilities (BDaero and BDana) presented differences amongst digestates depending on post-treatment applied. Indeed, composted or dried solid fractions of digestate were characterized by low $\mathrm{CH}_{4}$ yields

and $\mathrm{BOD}\left(0-28 \mathrm{NLCH}_{4} \mathrm{~kg}^{-1} \mathrm{VS}\right.$ and 39.8-254.4 $\left.\mathrm{gO}_{2} \mathrm{~kg}^{-1} \mathrm{VS}\right)$ corresponding to BDana of $<0.5-5.2 \%$ CODtot and BDaero of 2.8-18.6\% CODtot. The solid fractions of digestate showed higher values (41.1-93.8 $\mathrm{NLCH}_{4} \mathrm{~kg}^{-1} \mathrm{VS}$, BDana=7.2-18.6 \% CODtot and 237.0-550.0 $\left.\mathrm{gO}_{2} \mathrm{~kg}^{-1} \mathrm{VS}, \mathrm{BDaero}=14.6-38.0 \% \mathrm{CODtot}\right)$. These results demonstrated that the composting step of the solid fraction significantly reduce the biodegradable OM 
content. Among the solid fraction composts, A4C was characterized by the lowest biodegradability under both aerobic and anaerobic conditions (BDana<0.5\% and BDaero $=2.8 \%$ CODtot), thus suggesting that the $\mathrm{OM}$ of $\mathrm{A} 4 \mathrm{C}$ was the most stable of all studied samples. For solid fractions, A1S presented highest biodegradable COD under both conditions (BDana $=18.6 \%$ and BDaero $=38 \%$ CODtot). The total retention time of the treatment line for A1S was short (between 14 and 20 days, table 1) when compared to the other digestates (between 15 and 95 days). This could explain the important part of residual biodegradability in this digestate. The values of biodegradability for the solid fractions were in the range of values previously obtained by Bayard et al. in 2005 . These authors reported that the BDana of digestates from AD of residual municipal solid waste or biowaste ranged between 14.6 and $31.4 \%$ COD and the BDaero ranged between 19.8 and $44.1 \%$ COD. Consequently, despite the digestion process, certain digestates still contained a significant portion of residual biodegradable $\mathrm{OM}$, as has been previously reported (Teglia et al., 2011; Bayard et al., 2015). Depending on the post-treatment conditions, this portion can be more or less important. In terms of biodegradability, the differences observed between digestates were probably due to the differences in the structure of OM. The characterization of OM by chemical sequential extractions describing the accessibility of OM (\% CODtot for each extract) showed that the remaining $\mathrm{OM}$ in all digestates was essentially composed of less accessible fractions (SEOM+PEOM=25-78 \% CODtot). The most accessible fractions SPOM+REOM only represented 2.7-10.6\% CODtot. In terms of accessibility, no difference was observed between digestates. Teglia et al. (2011) reported similar results: the remaining OM of digestate and composted digestate obtained after digestion of food processing waste, agricultural wastes, organic fraction of municipal solid waste and sludge of wastewater 
treatment plant, mostly comprised slowly biodegradable OM. These authors demonstrated that the easily biodegradable fraction of OM ranged between 2.7 and 6.3 $\%$ COD with no observable distinction between raw digestates and composted digestates. The non-extracted fraction (NEOM), calculated according to the extracted fractions, represented a large part of CODtot (between 15.3-70.8\%). For most of the digestates (10 out of 14) the NEOM fraction represented more than $40 \%$ CODtot.

Jimenez et al. (2015) reported that the NEOM of sludge digestate ranged from 30.0 to $43.1 \%$ CODtot with more than $40 \%$ CODtot for the digested sludge compost. In the present study, the composted or dried digestates, excepting two composted digestates (A3C and SL1C, <20\% CODtot), also presented a NEOM fraction greater than $40 \%$ CODtot.

\subsection{Correlation between both aerobic and anaerobic biodegradabilities}

Fig. 1 illustrates linear positive correlations between anaerobic and aerobic biodegradabilities (BDana, BDaero) and between $\mathrm{CH}_{4}$ yield and parameters obtained from respirometry data $\left(\mathrm{BOD}, \mathrm{AT}_{4}\right.$ and $\left.\mathrm{DRI}_{24}\right)$ for the 14 post-treated digestates.

Concerning the anaerobic biodegradability, the mean value of the $\mathrm{CH}_{4}$ yield measured in duplicate was chosen for Fig. 1 because values indicated a good reproducibility (coefficient of variation $<15 \%$, data not shown).

Significant positive correlations were obtained between BDana and BDaero and between $\mathrm{CH}_{4}$ yield and BOD $\left(\mathrm{R}^{2}=0.8\right)$, whereas the correlations between $\mathrm{CH}_{4}$ yield and $\mathrm{AT}_{4}$ and between $\mathrm{CH}_{4}$ yield and $\mathrm{DRI}_{24}$ were less significant $\left(\mathrm{R}^{2}\right.$ of 0.7 and 0.6 , respectively). This was due to the underestimation of the aerobic biodegradability of one digestate, A1S (point surrounded on Fig. 1b and Fig. 1c), using $\mathrm{AT}_{4}$ and $\mathrm{DRI}_{24}$. 
Indeed, this sample presented the slowest respirometric kinetic, with an oxygen uptake rate of about $40 \mathrm{mmO}_{2} \mathrm{~h}^{-1} \mathrm{~kg}^{-1} \mathrm{VS}$ after $200 \mathrm{~h}$, and three clear OUR peaks (Fig. 3b). Short-term aerobic indices such as $\mathrm{AT}_{4}$ and $\mathrm{DRI}_{24}$ appeared to be insufficient to represent the overall biodegradability of this type of substrate still highly biodegradable and with a high activity level for a longer period of time. The biodegradability is, in this case, better estimated with the BOD value.

A significant positive correlation between both aerobic and anaerobic biodegradabilities and biological indices has been observed in previous studies considering raw waste or organic residues during composting treatment (Binner and Zach, 1999; Cossu and Raga, 2008; Barrena et al., 2009; Bohm et al., 2010; Liu et al., 2015). Few studies have reported this correlation for digestates. Bayard et al. (2015) demonstrated a linear regression between both biodegradabilities for four substrates and four raw digestates from residual municipal solid waste and biowaste. Schievano et al. (2008) also reported a positive correlation between anaerobic biogasification potential and $\mathrm{O}_{2}$ uptake rate on 46 samples including waste mixtures (agricultural, agro-industrial wastes and organic fraction of municipal solid waste) and their raw digestates. Finally, Ponsa et al. (2008) described a positive and linear correlation between aerobic and anaerobic stability indices for organic solid wastes during different stages of biodegradation including raw digestates and digestates post-treated by composting. Hence, the present study appears to be the first that has demonstrated a significant correlation between both aerobic and anaerobic indices for digestate samples posttreated by phase separation and composting.

Interestingly, the slope of the linear correlation between BDaero and BDana (1.8, Fig. 1d) suggested that the OM contained in all digestates was less biodegradable 
under anaerobic conditions than aerobic conditions. This result on digestate samples has already been obtained by Bayard et al. (2015) on raw digestates from AD of residual municipal solid waste and biowaste. According to Monlau et al. (2012), certain biodegradable parts are not accessible to microorganisms during $\mathrm{AD}$, most likely due to the compositional and structural characteristics of ligno-cellulosic materials. Wagland et al. (2009) also reported that microbial growth efficiency under anaerobic conditions was lower than under aerobic conditions.

Consequently the $\mathrm{CH}_{4}$ yield and BOD constitute good indicators for describing the biodegradability and the stability of digestates. They can thus also represent useful tools for assessing the efficiency of biological treatment process (Cossu and Raga, 2008; Ponsá et al., 2008; Barrena et al., 2009; Bayard et al., 2015).

\subsection{Relation between biodegradability, accessibility and complexity of $O M$}

The full dataset was analysed though PCA in order to highlight correlations between the aerobic and anaerobic biodegradabilities (BDana and BDaero), the accessibility of $\mathrm{OM}$ and its complexity, obtained by combining chemical extractions and fluorescence spectroscopy. The two major components, PCA1 and PCA2, were sufficient to describe $76.3 \%$ of the data variability (Fig. 2). The PCA1 essentially describes the complexity of each accessible fraction (1-7 zones) and the aerobic and anaerobic biodegradabilities, while the PCA2 mainly describes the chemical accessibility of OM. The PCA correlation circles also illustrated that BDana and BDaero were particularly well correlated with the variables describing the first component, i. e. the OM complexity. The low correlation values between digestate biodegradability and OM accessibility was confirmed by a Pearson's correlation 
analysis for BDana, BDaero and \%CODtot of each extracted fraction of OM (Table 3).

Indeed, this analysis demonstrated that the BDana and BDaero biodegradabilities only correlated with the most easily accessible fraction $\operatorname{SPOM}\left(\mathrm{R}^{2}=0.8\right.$ and 0.6 , respectively), and not with the other accessible fractions REOM, SEOM and PEOM. Likewise, Bayard et al. (2015) studied the correlations between the BMP and different OM fractions. These authors pointed to a significant positive correlation between BMP and water soluble COD, and negative correlations between BMP and Van Soest residual fraction and humic substances, respectively. Here, the PCA correlation circle (Fig 2a) illustrated that the two biodegradability indicators were positively correlated with the simplest forms of molecules (zones 1-3 of complexity related to fluorescence) and were negatively correlated with complex molecules (zones 4-7 of complexity related to fluorescence) such as fulvic acid-, melanoidin-, lignocellulose- or humic acid-like molecules. The previous correlations between anaerobic biodegradability and $\mathrm{OM}$ complexity have already been reported in studies carried out on wastes intended for AD processes (Gunaseelan, 2007) or treated by AD (Jimenez et al., 2014).

The PCA1 axis governed the classification of digestates into two distinct groups (Fig. 2b). Composted and dried solid fractions of digestate were clearly separated from solid fractions of digestate, revealing that the composting post-treatment step significantly affected the biological and biochemical properties of digestate. This has also been reported by Bayard et al. (2015) on substrates and digestates from biowaste and residual municipal solid waste. Composted and dried solid fractions of digestate were characterized by low aerobic and anaerobic biodegradabilities. They mostly contained the slowly accessible fraction SEOM associated to humic-like substances including complex molecules (zones 4-7 of complexity related to fluorescence) as 
reported by Jimenez et al. (2015). Indeed, the complexity of composted solid fractions of digestate could be attributed to humic and fulvic acid-like and lignocellulosic-like compounds found in fluorescence zones 4-7 of the easily and slowly accessible fractions (SPOM+REOM+SEOM), which are known to be recalcitrant and slowly biodegradable. Inversely, solid fractions of digestate without a composting posttreatment were characterized by high amounts of aerobic and anaerobic biodegradability indicators and contained a large part of easily accessible fraction (SPOM) comprising simple forms of molecules. Solid fractions of digestate contained proteins molecules observed in fluorescence zones 1-3 of easily and slowly accessible fractions (SPOM+REOM+SEOM).

These results suggest that $\mathrm{OM}$ contained in digestates present different levels of complexity according to the applied post-treatment. Composted or dried solid fractions of digestate characterized by low biodegradability and high complexity were found to be more stable than solid digestate fractions, thus allowing for their agricultural re-use by land spreading (Ponsá et al.,2008; Teglia et al., 2011). On the contrary, the solid digestate fractions, which were characterized by a higher biodegradability and lower complexity, should most likely be subjected to a complete composting step or to a storage period in order to ensure their stabilization before they can be re-used for agricultural purposes. Although the impact of post-treatments on the biodegradability of organic matter in solid-fractions of digestate was here demonstrated, it must be pointed out that other factors such as types of feedstocks or digester operating conditions can also impact the organic matter properties of digestates. Finally, OM characterization using fluorescence spectroscopy is easier and faster to perform than aerobic and 
anaerobic tests; it could therefore be applied to evaluate the biodegradability and thus the status of digestate as a relatively stabilized fertilizer.

\subsection{Kinetics of respirometric activity}

Only the respirometric kinetics have been taken into account in the results.

Indeed, the $\mathrm{O}_{2}$ uptake rate was measured more frequently (every $2 \mathrm{~min}$ ) than the $\mathrm{CH}_{4}$ production rate (twice a week). During the respirometric experiments, the OUR kinetics showed various profiles according to the studied digestate (Fig. 3). Nine digestates, including all the dried and composted solid fractions of digestate, were characterized by a profile with only one peak of $\mathrm{O}_{2}$ consumption, followed by a decrease of activity until endogenous respiration (Fig. 3a). These profiles were classical on solid organic wastes, such as municipal waste (Adhikari et al.,2013) or mixtures of sludge and bulking agent (Mohajer et al., 2009). At the opposite, five digestates showed atypical profiles with a second (SL1S, T1S, T2S, T3S and A1S) and a third OUR peak (T3S and A1S) before reaching the endogenous respiration (Fig. 3b). Atypical OUR kinetics could be explained by combining two phases of OM biodegradation according to (i) the $\mathrm{OM}$ accessibility and/or (ii) the released OM components, that both changed with time.

The applied AD process (e.g., temperature and retention time) and the type of treated waste could also impact the OM composition of the obtained digestate as well as its respirometric profile. Atypical kinetics with two OUR peaks have already been reported by Zeng et al. (2016) in a study on digestates obtained after thermophilic AD of municipal solid waste. Atypical kinetics were here observed in digestates from both mesophilic (T1S, T2S, T3S) and thermophilic (A1S and SL1S) AD processes, and with different treated wastes (agriculture waste, territorial waste, urban sludge). These results 
demonstrate that the type of digestion process and the nature of treated waste do not seem to explain the observed atypical kinetics of respirometric activity.

In order to understand the appearance of two or three OUR peaks, a PCA was carried out on the different parameters describing the OM accessibility, its complexity and the fractionation of BDaero into MBi and $\mathrm{MHi}(\mathrm{i}=1,2$ or 3 ) according to the number of OUR peaks (calculations described in 2.3.1) (Fig. 4). Two components, PCA1 and PCA2, were sufficient to describe $67.4 \%$ of the data variability. Variables describing the PCA1 axis were MB1 which characterized the easily biodegradable OM linked to the first OUR peak, and the fluorescence-related complexity of each accessible fraction (zones 1-7). As for the previous results, the variable describing the PCA2 axis was the chemical accessibility of OM. MB1 was positively correlated with the simpler molecules of OM fractions (Fig. $4 \mathrm{a}$ and $\mathrm{R}^{2}$ of the correlation between MB1 and fluorescence zones $1-3$ of SPOM+REOM+SEOM = 0.5-0.7, $p$-values $<0.05$, data not shown). Even with the data description using the other PCA axes, the other MBi and MHi axes were not significantly correlated with the accessibility and/or the complexity (data not shown). Moreover, axes of PCA led to the separation from other digestates of four out of the five digestates presenting atypical kinetics (Fig. 4b). The parameters then used to describe the $\mathrm{OM}$ in this study were not sufficient and/or relevant to explain the observed atypical OUR kinetics. Further work is still required for a better comprehension of the observed multiple peaks. For example, during the respirometric test, enzymatic activities and bacterial and fungal community composition (by highthroughput sequencing analysis) could also contribute to the evolution of the nature of the OM. Moreover, the aqueous compartment of OM could be characterized in terms of apparent molecular weight by size exclusion chromatography. 


\section{Conclusions}

Solid fractions were found to comprise a significant part of remaining biodegradable OM despite the digestion process. Composted solid fractions were characterized by low biodegradable OM containing complex molecules, thus implying the presence of a more stable OM. The relation between complexity and biodegradability that has been demonstrated in this study has allowed for the effect of post-treatments on the stability of digestates to be better understood. Consequently, these data on OM stability should contribute to the improvement of agricultural re-use of digestates as fertilizers.

An example of decomposition of a spectra obtained by fluorescence spectroscopy analysis into seven zones of fluorescence is presented in the Supplementary Figure 1.

\section{Acknowledgement}

This research was financially supported by the Agence de l'Environnement et de la Maitrise de l'Energie (ADEME) (grant number: 1306C0032).

\section{References}

1. Adhikari, B., Tremier, A., Barrington, S., Martinez, J., 2013. Biodegradability of municipal organic waste: a respirometric test. Waste Biomass Valor. 4, 331-340.

2. Barrena, R., d’Imporzano, G., Ponsà, S., Gea, T., Artola, A., Vazquez, F., Sancheza, A., Adani, F., 2009. In search of a reliable technique for the determination of the 
biological stability of the organic matter in the mechanical-biological treated waste.

J. Hazard. Mater. 162(2-3), 1065-1072. doi:10.1016/j.jhazmat.2008.05.141

3. Bayard, R., Gonzalez-Ramirez, L., Guendouz, J., Benbelkacem, H., Buffiere, P., Gourdon, R., 2015. Statistical Analysis to Correlate Bio-physical and Chemical Characteristics of Organic Wastes and Digestates to Their Anaerobic Biodegradability. Waste Biomass Valor. 6(5), 759-769. doi:10.1007/s12649-015$9411-2$

4. Berthe, L., Druilhe, C., Massiani, C., Tremier, A., de Guardia, A., 2007. Coupling a respirometer and a pycnometer, to study the biodegradability of solid organic wastes during composting. Biosyst. Eng. 97, 75-88.

5. Binner, E., Zach, A., 1999. Laboratory tests describing the biological reactivity of pretreated residual wastes. ORBIT 99 Organic Recovery and Biological Treatment, $255-261$.

6. Böhm, K., Smidt, E., Binner, E., Schwanninger, M., Tintner, J., Lechner, P., 2010. Determination of MBT-waste reactivity - An infrared spectroscopic and multivariate statistical approach to identify and avoid failures of biological tests. Waste Manage. 30(4), 583-590. doi:10.1016/j.wasman.2009.09.037

7. Cossu, R., Raga, R., 2008. Test methods for assessing the biological stability of biodegradable waste. Waste Manage. 28(2), 381-388.

doi:10.1016/j.wasman.2007.01.014

8. Godley, A. R., Lewin, K., Graham, A., Barker, H., Smith, R., 2004. Biodegradability determination of municipal waste: an evaluation of methods. Proc. Waste 2004 Conf. Integrated Waste Management and Pollution Control: Policy and Practice, Research and Solutions. Stratford-upon-Avon, UK, 28-30 September, 40-49. 
9. Gunaseelan, V. N., 2007. Regression models of ultimate methane yields of fruits and vegetable solid wastes, sorghum and napiergrass on chemical composition.

Bioresour. Technol. 98(6), 1270-1277. doi:10.1016/j.biortech.2006.05.014

10. Jimenez, J., Aemig, Q., Doussiet, N., Steyer, J. P., Houot, S., Patureau, D., 2015. A new organic matter fractionation methodology for organic wastes: Bioaccessibility and complexity characterization for treatment optimization. Bioresour. Technol. 194, 344-353. doi:10.1016/j.biortech.2015.07.037

11. Jimenez, J., Gonidec, E., Cacho Rivero, J. A., Latrille, E., Vedrenne, F., Steyer, J. P., 2014. Prediction of anaerobic biodegradability and bioaccessibility of municipal sludge by coupling sequential extractions with fluorescence spectroscopy: Towards ADM1 variables characterization. Water Res. 50, 359-372. doi:10.1016/j.watres.2013.10.048

12. Liu, X., Bayard, R., Benbelkacem, H., Buffiere, P., Gourdon, R., 2015. Evaluation of the correlations between biodegradability of lignocellulosic feedstocks in anaerobic digestion process and their biochemical characteristics. Biomass Bioenergy 81, 534543. doi:10.1016/j.biombioe.2015.06.021

13. Mohajer, A., Trémier, A., Barrington, S., Martinez, J., Teglia, C., Carone, M. 2009. Microbial oxygen uptake in sludge as influenced by compost physical parameters. Waste Manage. 29(8), 2257-2264. doi:10.1016/j.wasman.2009.03.017

14. Monlau, F., Sambusiti, C., Barakat, A., Guo, X. M., Latrille, E., Trably, E., Steyer, J. P., Carrere, H., 2012. Predictive models of biohydrogen and biomethane production based on the compositional and structural features of lignocellulosic materials. Environ. Sci. Technol. 46(21), 12217-12225. doi:10.1021/es303132t 
15. Muller, M., Jimenez, J., Antonini, M., Dudal, Y., Latrille, E., Vedrenne, F., ... Patureau, D. (2014). Combining chemical sequential extractions with 3D fluorescence spectroscopy to characterize sludge organic matter. Waste Manage, 34(12), 2572-2580. doi:10.1016/j.wasman.2014.07.028

16. Ponsá, S., Gea, T., Alerm, L., Cerezo, J., Sánchez, A., 2008. Comparison of aerobic and anaerobic stability indices through a MSW biological treatment process. Waste Manage. 28(12), 2735-2742. doi:10.1016/j.wasman.2007.12.002

17. Ponsá, S., Gea, T., Sánchez, A., 2010. Different indices to express biodegradability in organic solid wastes. J. Environ. Qual. 39, 706-712. doi: $10.2134 /$ jeq2009.0294

18. Raposo, F., Fernandez-Cegri, V., de la Rubia, M. A., Borja, R., Béline, F., Cavinato, C., Demirer, G., Fernandez, B., Fernandez-Polanco, M., Frigon, J.-C., Ganesh, R., Kaparaju, P., Koubova, J., Mendez, R., Menin, G., Peene, A., Scherer, P., Torrijos, M., Uellendahl, H., Wierinckm, I., de Wilde, V., 2011. Biochemical methane potential (BMP) of solid organic substrates: Evaluation of anaerobic biodegradability using data from an international interlaboratory study. J Chem Technol Biotechnol, 86(8), 1088-1098. doi:10.1002/jctb.2622

19. Scaglia, B., Confalonieri, R., D’Imporzano, G., Adani, F., 2010. Estimating biogas production of biologically treated municipal solid waste. Bioresour. Technol. 101(3), 945-952. doi:10.1016/j.biortech.2009.08.085

20. Schievano, A., Pognani, M., D’Imporzano, G., Adani, F., 2008. Predicting anaerobic biogasification potential of ingestates and digestates of a full-scale biogas plant using chemical and biological parameters. Bioresour. Technol. 99(17), 8112-8117. doi:10.1016/j.biortech.2008.03.030 
21. Tambone, F., Scaglia, B., D’Imporzano, G., Schievano, A., Orzi, V., Salati, S., Adani, F., 2010. Assessing amendment and fertilizing properties of digestates from anaerobic digestion through a comparative study with digested sludge and compost. Chemosphere 81(5), 577-583. doi:10.1016/j.chemosphere.2010.08.034

22. Teglia, C., Tremier, A., Martel, J.-L., 2010. Characterization of Solid Digestates: Part 1, Review of Existing Indicators to Assess Solid Digestates Agricultural Usé. Waste Biomass Valor. 2(1), 43-58. doi:10.1007/s12649-010-9051-5

23. Teglia, C., Tremier, A., Martel, J.-L., 2011. Characterization of Solid Digestates: Part 2, Assessment of the Quality and Suitability for Composting of Six Digested Products. Waste Biomass Valor. 2(2), 113-126. doi:10.1007/s12649-010-9059-x

24. Tremier, A., de Guardia, A., Massiani, C., Paul, E., Martel, J.L., 2005. A respirometric method for characterising the organic composition and biodegradation kinetics and the temperature influence on the biodegradation kinetics, for a mixture of sludge and bulking agent to be co-composted. Bioresour. Technol. 96: 169-180.

25. Wagland, S. T., Tyrrel, S. F., Godley, A.R., Smith, R. 2009. Test methods to aid in the evaluation of the diversion of biodegradable municipal waste (BMW) from landfill. Waste Manage. 29, 1218-1226.

26. Zeng, Y., De Guardia, A., Dabert, P., 2016. Improving composting as a posttreatment of anaerobic digestate. Bioresour. Technol. 201, 293-303.

\section{Figure Captions}

Fig. 1. Correlations between BOD and $\mathrm{CH}_{4}$ yield (a), $\mathrm{AT}_{4}$ and $\mathrm{CH}_{4}$ yield (b), $\mathrm{DRI}_{24}$ and $\mathrm{CH}_{4}$ yield (c), and BDaero and BDana (d) of digestates (white diamonds: solid fractions 
of digestate; black circles: composted or dried solid fractions). The mean for duplicates are given for the $\mathrm{CH}_{4}$ yield and the BDana is calculated from these mean values.

Fig. 2. Principal Components Analysis on biodegradabilities and organic matter characterization: variables on correlation circle (a) (square symbol for BDana and BDaero, triangle for \%CODtot of extracted OM fractions and NEOM and circle for complexity related to fluorescence of each extractable fraction) and distribution of digestates (b) (solid fractions of digestate in white circles and composted or dried solid fractions in black circles). SP, RE, SE, PE and NE correspond to SPOM, REOM, SEOM, PEOM and NEOM respectively. sp1-7, re1-7, se1-7 and pe1-7 correspond to fluorescence zones (1-7) of extractable fractions SPOM, REOM, SEOM and PEOM, respectively.

Fig. 3. Kinetics of respirometric activity during the first $600 \mathrm{~h}$ for digestates classified according to the number of OUR peaks: digestates with only one peak (a) and digestates with two or three peaks (b).

Fig. 4. Principle Components Analysis on respirometric kinetics and organic matter characterization: variables on correlation circle (a) (square symbols for MBi and MHi, triangles for \%CODtot of extracted OM fractions and NEOM and circles for complexity related to fluorescence of each accessible fraction) and distribution of digestates (b). SP, RE, SE, PE and NE correspond to SPOM, REOM, SEOM, PEOM and NEOM respectively. sp1-7, re1-7, se1-7 and pe1-7 correspond to fluorescence zones (1-7) of each extractable fraction SPOM, REOM, SEOM and PEOM, respectively. 


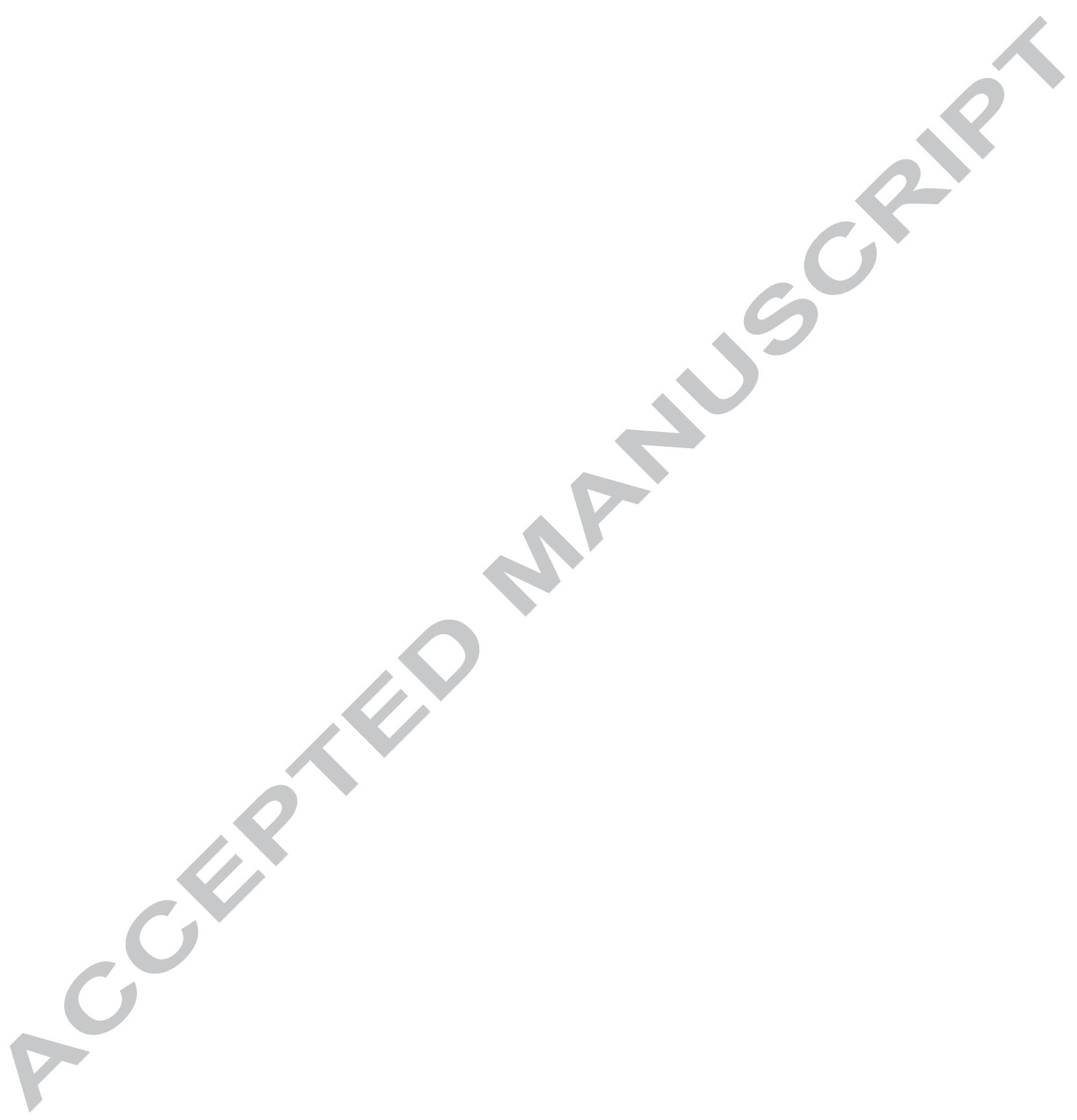

Comment citer ce document :

Maynaud, G., Druilhe, C., Daumoin, M., Jimenez, J., Patureau, D., Torrijos, M., Pourcher, A.-M., Wéry, N. (Auteur de correspondance) (2017). Characterisation of the biodegradability of post-treated digestates via the chemical accessibility and complexity of organic matter. Bioresource 
Table 1. Digestate designation and origin.

\begin{tabular}{|c|c|c|c|c|c|c|c|}
\hline \multirow[b]{2}{*}{ Digestate $^{\mathrm{a}}$} & \multirow[b]{2}{*}{ Nature } & \multirow[b]{2}{*}{ Main digester feedstock ${ }^{\mathrm{b}}$} & \multirow[b]{2}{*}{$\begin{array}{l}\text { Ton of digested } \\
\text { waste (T/year) }\end{array}$} & \multicolumn{3}{|c|}{ Digestion process } & \multirow[b]{2}{*}{$\begin{array}{l}\text { Phase separation } \\
\text { of digestate }\end{array}$} \\
\hline & & & & Type of AD & $\begin{array}{l}\text { Total RT } \\
\text { (days) }\end{array}$ & $\begin{array}{l}\text { Temperature } \\
\left({ }^{\circ} \mathrm{C}\right)\end{array}$ & \\
\hline SL1S & Solid fraction & WWTP sludge & 4000 & Wet & 15 & 55 & Centrifugation \\
\hline SL2S & Solid fraction & WWTP sludge & $-c$ & Wet & $20-30$ & 37 & $\begin{array}{l}\text { Thermal centrifugation } \\
\text { and filter press }\end{array}$ \\
\hline A1S & Solid fraction & Manure & 12000 & Wet & $14-20$ & $53-55$ & Screw press \\
\hline T1S & Solid fraction & FPW, slurry & 35000 & Wet & 60 & 38 & Centrifugation \\
\hline $\mathrm{T} 2 \mathrm{~S}$ & Solid fraction & FPW & 20000 & Wet & $90-95 *$ & 40 & Screw press \\
\hline T3S & Solid fraction & $\begin{array}{l}\text { FPW, green waste, fat, WWTP } \\
\text { sludge }\end{array}$ & 30000 & Wet & $47-52 *$ & 37 & Screw press \\
\hline $\mathrm{T} 4 \mathrm{~S}$ & Solid fraction & FPW, WWTP sludge, manure & - & Wet & $75-85^{*}$ & 37 & Screw press \\
\hline $\mathrm{A} 2 \mathrm{D}$ & $\begin{array}{l}\text { Dried and composted } \\
\text { solid fraction }\end{array}$ & $\begin{array}{l}\text { Slurry, biowaste, WWTS } \\
\text { sludge, fat }\end{array}$ & 12000 & Wet & $44^{*}$ & 38 & Centrifugation \\
\hline $\mathrm{A} 3 \mathrm{C}$ & Solid fraction compost & Manure, green waste & 5000 & Wet & $30-32$ & 40 & Centrifugation \\
\hline $\mathrm{A} 4 \mathrm{C}$ & Solid fraction compost & Manure, slurry, green waste & 6000 & Wet & 60 & 41 & Screw press \\
\hline SL2C & Solid fraction compost & WWTP sludge & - & Wet & $20-30$ & 37 & $\begin{array}{l}\text { Thermal centrifugation } \\
\text { and filter press }\end{array}$ \\
\hline $\mathrm{O} 1 \mathrm{C}$ & Solid fraction compost & OFMSW, FPW & 48000 & Dry & 21 & 37 or $55^{\mathrm{e}}$ & Screw press \\
\hline $\mathrm{O} 2 \mathrm{C}$ & Solid fraction compost & $\begin{array}{l}\text { OFMSW, green waste, fat, } \\
\text { FPW }\end{array}$ & 25000 & Wet & 21 & $53-57$ & $\begin{array}{l}\text { Screw press and } \\
\text { centrifugation }\end{array}$ \\
\hline M1C & Solid fraction compost & MSW, biowaste, green waste & 100000 & Dry & 21 & 38 & $\begin{array}{l}\text { Screw press and } \\
\text { band filter }\end{array}$ \\
\hline
\end{tabular}

${ }^{\mathrm{a}}$ A: agricultural waste, SL: urban sludge, T: territorial waste, O: organic fraction of municipal solid waste (OFMSW), M: municipal solid waste (MSW), S: solid fraction of digestate, D: dried and composted solid fraction of digestate, C: composted solid fraction of digestate, ${ }^{\mathrm{b}} \mathrm{WWTP}$ : wastewater treatment plant, FPW: food 
processing waste, ${ }^{\mathrm{c}}-$ : unknown, ${ }^{\mathrm{d}} \mathrm{RT}$ : retention time including the time of post-digestion when applied $(*)$, ${ }^{\mathrm{e}}$ sample results from the digestate mix originated from two reactors (one at $37^{\circ} \mathrm{C}$ and one at $55^{\circ} \mathrm{C}$ ) operating in parallel. 
Table 2. Physico-chemical and biological properties of digestates. Analysis of TS, VS, CODtot were performed in triplicate and $\mathrm{CH}_{4}$ yield in duplicate. The mean and the standard deviation are given for these analyses.

\begin{tabular}{|c|c|c|c|c|c|c|c|c|c|c|c|c|}
\hline \multirow{2}{*}{ Digestate $^{\mathrm{a}}$} & \multirow{2}{*}{ TS $(\%)$} & \multirow{2}{*}{ VS (\%TS) } & \multirow{2}{*}{$\begin{array}{l}\text { CODtot } \\
\left(\mathrm{gO}_{2} \mathrm{~kg}^{-1} \mathrm{VS}\right)\end{array}$} & \multirow{2}{*}{$\begin{array}{l}\mathrm{CH}_{4} \text { yield } \\
\left(\mathrm{NL} \mathrm{CH}_{4} \mathrm{~kg}^{-1} \mathrm{VS}\right)\end{array}$} & \multirow{2}{*}{$\begin{array}{l}\text { BOD } \\
\left(\mathrm{gO}_{2} \mathrm{~kg}^{-1} \mathrm{VS}\right)\end{array}$} & \multirow{2}{*}{$\begin{array}{l}\text { BDana } \\
\text { (\%CODtot) }\end{array}$} & \multirow{2}{*}{$\begin{array}{l}\text { BDaero } \\
\text { (\%CODtot) }\end{array}$} & \multicolumn{5}{|c|}{ Chemical sequential extraction (\% CODtot) } \\
\hline & & & & & & & & SPOM & REOM & SEOM & PEOM & NEOM \\
\hline SL1S & $22.3 \pm 0.2$ & $70.4 \pm 0.1$ & $1696 \pm 6$ & $83.7 \pm 3.8$ & 550.0 & 14.1 & 32.4 & 5.3 & 3.2 & 18.6 & 49.5 & 23.4 \\
\hline SL2S & $22.4 \pm 0.1$ & $51.7 \pm 0.5$ & $1311 \pm 44$ & $73.2 \pm 2.0$ & 332.1 & 16.0 & 25.3 & 5.6 & 4.6 & 10.4 & 48.4 & 31.0 \\
\hline A1S & $25.6 \pm 0.4$ & $86.5 \pm 0.4$ & $1439 \pm 13$ & $93.8 \pm 2.4$ & 546.9 & 18.6 & 38.0 & 6.6 & 4.1 & 11.2 & 32.9 & 45.2 \\
\hline $\mathrm{T} 1 \mathrm{~S}$ & $23.9 \pm 0.1$ & $74.3 \pm 0.1$ & $1554 \pm 12$ & $66.5 \pm 1.3$ & 368.1 & 12.2 & 23.7 & 4.1 & 3.6 & 11.1 & 24.8 & 56.4 \\
\hline $\mathrm{T} 2 \mathrm{~S}$ & $24.9 \pm 0.1$ & $80.1 \pm 2.2$ & $1615 \pm 14$ & $55.1 \pm 3.4$ & 492.6 & 9.7 & 30.5 & 2.7 & 2.1 & 4.2 & 34.3 & 56.7 \\
\hline $\mathrm{T} 3 \mathrm{~S}$ & $26.4 \pm 0.3$ & $82.6 \pm 0.6$ & $1508 \pm 13$ & $48.0 \pm 7.3$ & 446.2 & 9.1 & 2.00 & 3.0 & 2.2 & 8.0 & 40.3 & 46.5 \\
\hline $\mathrm{T} 4 \mathrm{~S}$ & $22.8 \pm 0$ & $61.0 \pm 0.5$ & $1627 \pm 44$ & $41.1 \pm 0.9$ & 237.0 & 7.2 & 14.6 & 1.9 & 2.4 & 7.0 & 17.9 & 70.8 \\
\hline A2D & $74.6 \pm 0.8$ & $61.3 \pm 0.1$ & $1366 \pm 10$ & $19.1 \pm 0.3$ & 122.7 & 4.0 & 9.0 & 2.1 & 1.9 & 15.8 & 37.6 & 42.6 \\
\hline A3C & $43.9 \pm 0.4$ & $51.7 \pm 0.4$ & $1530 \pm 35$ & $17.5 \pm 0.6$ & 177.8 & 3.3 & 11.6 & 3.1 & 3.8 & 30.3 & 47.5 & 15.3 \\
\hline $\mathrm{A} 4 \mathrm{C}$ & $40.9 \pm 1.7$ & $47.0 \pm 2.4$ & $1425 \pm 138$ & $<0.5$ & 39.8 & 0.0 & 2.8 & 1.5 & 3.8 & 20.2 & 19.6 & 54.9 \\
\hline SL2C & $59.1 \pm 0.8$ & $50.4 \pm 7.3$ & $1440 \pm 61$ & $14.6 \pm 0.2$ & 93.0 & 2.9 & 6.5 & 5.0 & 4.8 & 24.9 & 46.0 & 19.3 \\
\hline $\mathrm{O} 1 \mathrm{C}$ & $60.1 \pm 1.1$ & $46.6 \pm 1.0$ & $1245 \pm 15$ & $22.7 \pm 0.2$ & 152.7 & 5.2 & 12.3 & 3.7 & 1.5 & 7.5 & 42.9 & 44.4 \\
\hline $\mathrm{O} 2 \mathrm{C}$ & $53.3 \pm 1.2$ & $39.3 \pm 1.7$ & $1367 \pm 133$ & $17.8 \pm 0.6$ & 254.4 & 3.7 & 18.6 & 1.6 & 1.1 & 4.1 & 34.0 & 59.2 \\
\hline M1C & $55.8 \pm 0.3$ & $42.1 \pm 1.1$ & $1541 \pm 38$ & $28.0 \pm 0.4$ & 176.1 & 5.2 & 11.4 & 2.1 & 2.2 & 6.8 & 29.7 & 59.2 \\
\hline
\end{tabular}

${ }^{a}$ A: agricultural waste, SL: urban sludge, T: territorial waste, O: organic fraction of municipal solid waste (OFMSW), M: municipal solid waste (MSW), S: solid fraction of digestate, D: dried and composted solid fraction of digestate, C: composted solid fraction of digestate. 
Table 3. Pearson's $r$ correlation analysis between biodegradability under anaerobic (BDana) and aerobic (BDaero) conditions and \%CODtot of each extracted fraction of OM (SPOM, REOM, SEOM and PEOM). Significant correlations (*** p-values $<0.001$, ** p-values $<0.01$ and $*$ p-values $<0.05$ ) are in bold.

\begin{tabular}{lllllll}
\hline & BDana & BDaero & SPOM & REOM & SEOM & PEOM \\
\hline BDana & 1.0 & $\mathbf{0 . 9} * * *$ & $\mathbf{0 . 8}^{* *}$ & 0.3 & -0.3 & 0.2 \\
BDaero & & 1.0 & $\mathbf{0 . 6}^{*}$ & 0.0 & -0.4 & 0.2 \\
SPOM & & & 1.0 & $\mathbf{0 . 6}^{*}$ & 0.2 & 0.5 \\
REOM & & & & 1.0 & $\mathbf{0 . 6 *}$ & 0.2 \\
SEOM & & & & & 1.0 & 0.4 \\
PEOM & & & & & & 1.0 \\
\hline
\end{tabular}


Fig. 1.

a.

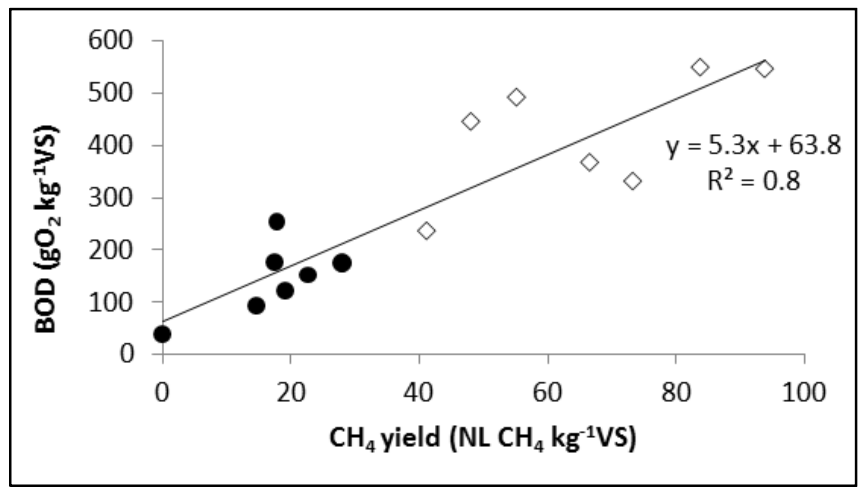

b.

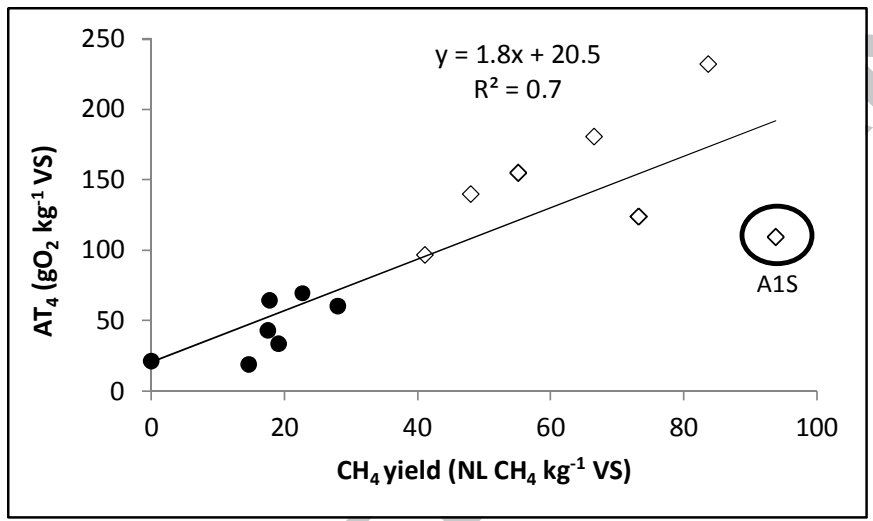

c.

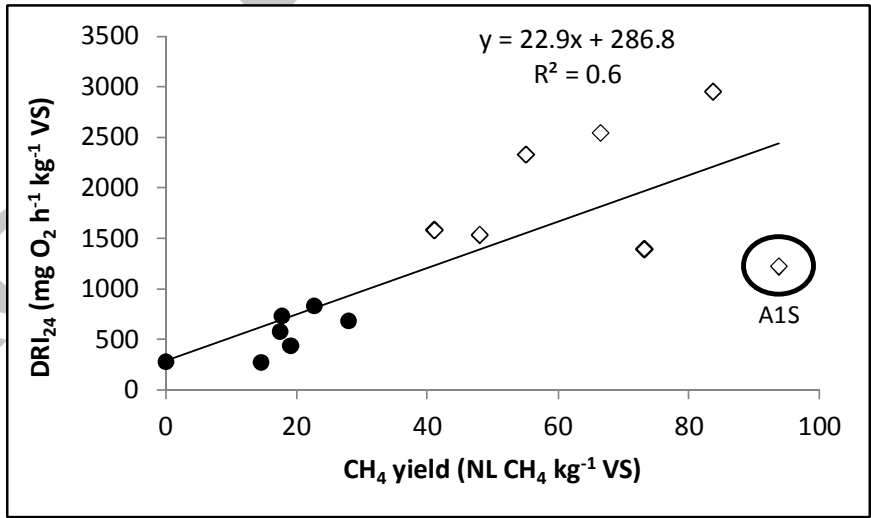

d. 


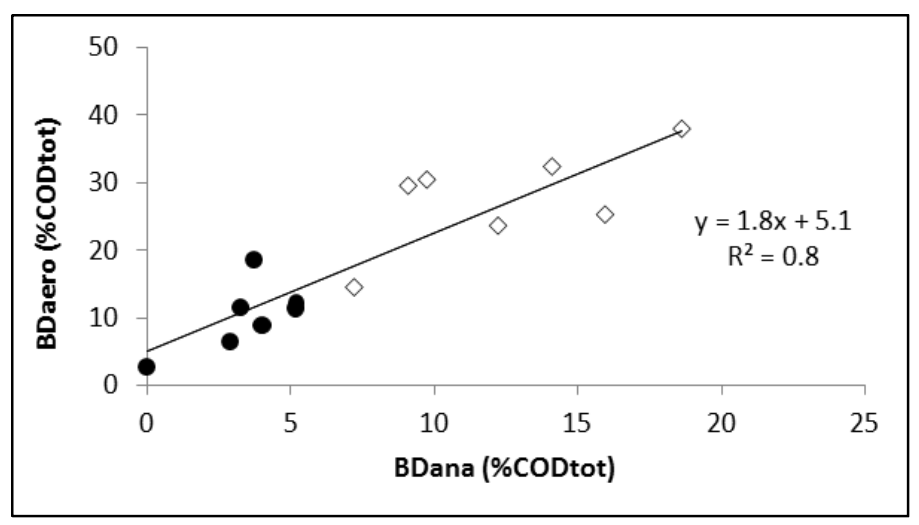


Fig. 2.

(a)

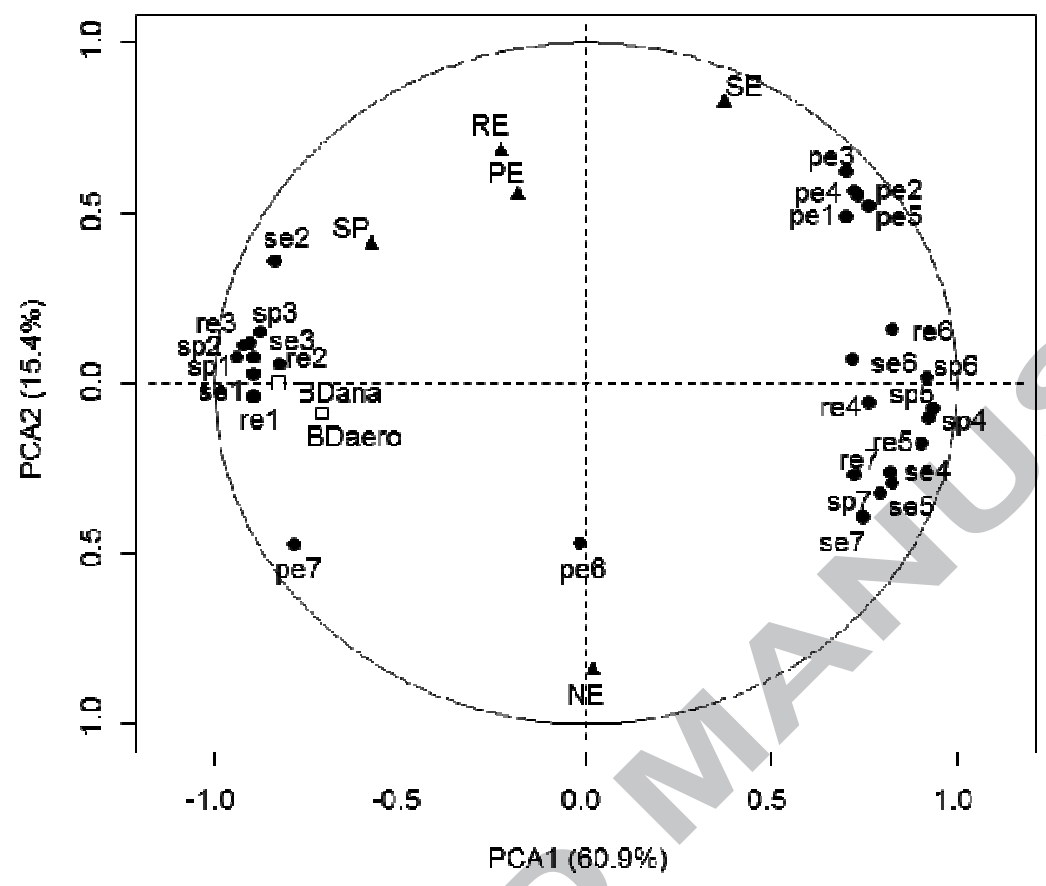

(b)

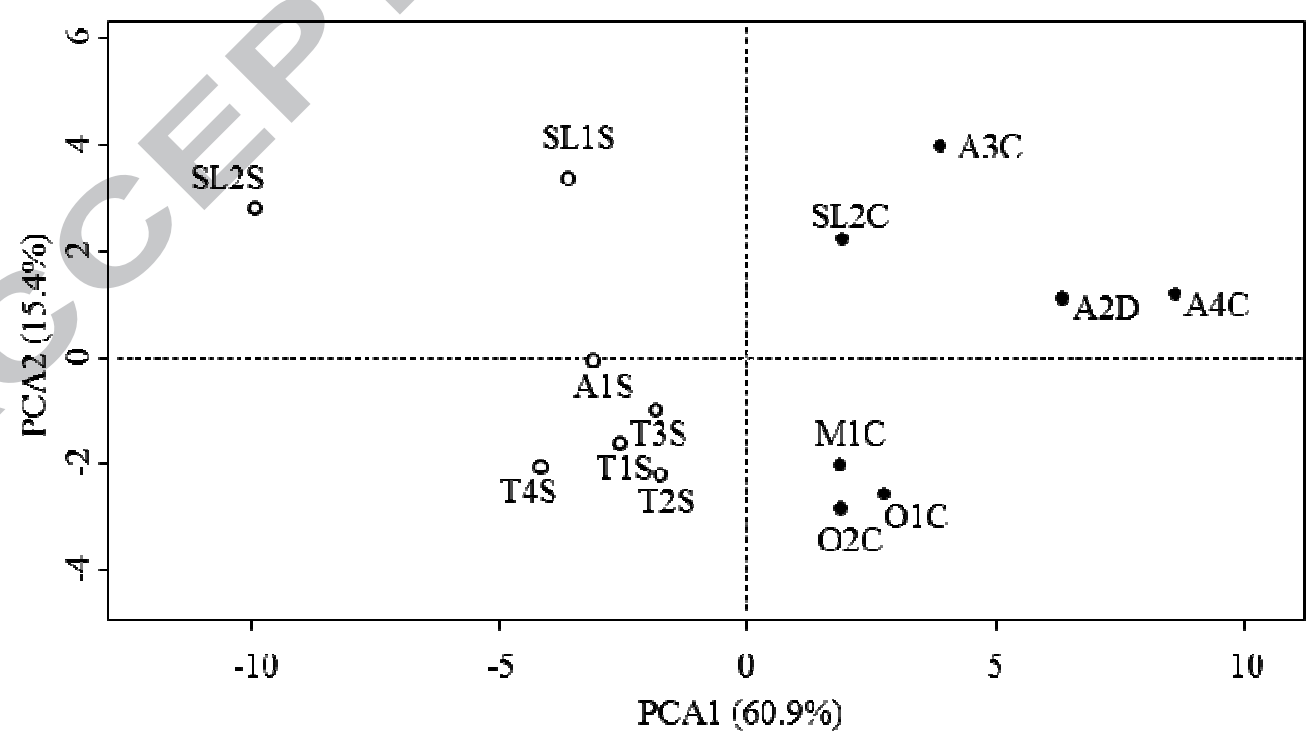




\section{Fig. 3.}

(a)

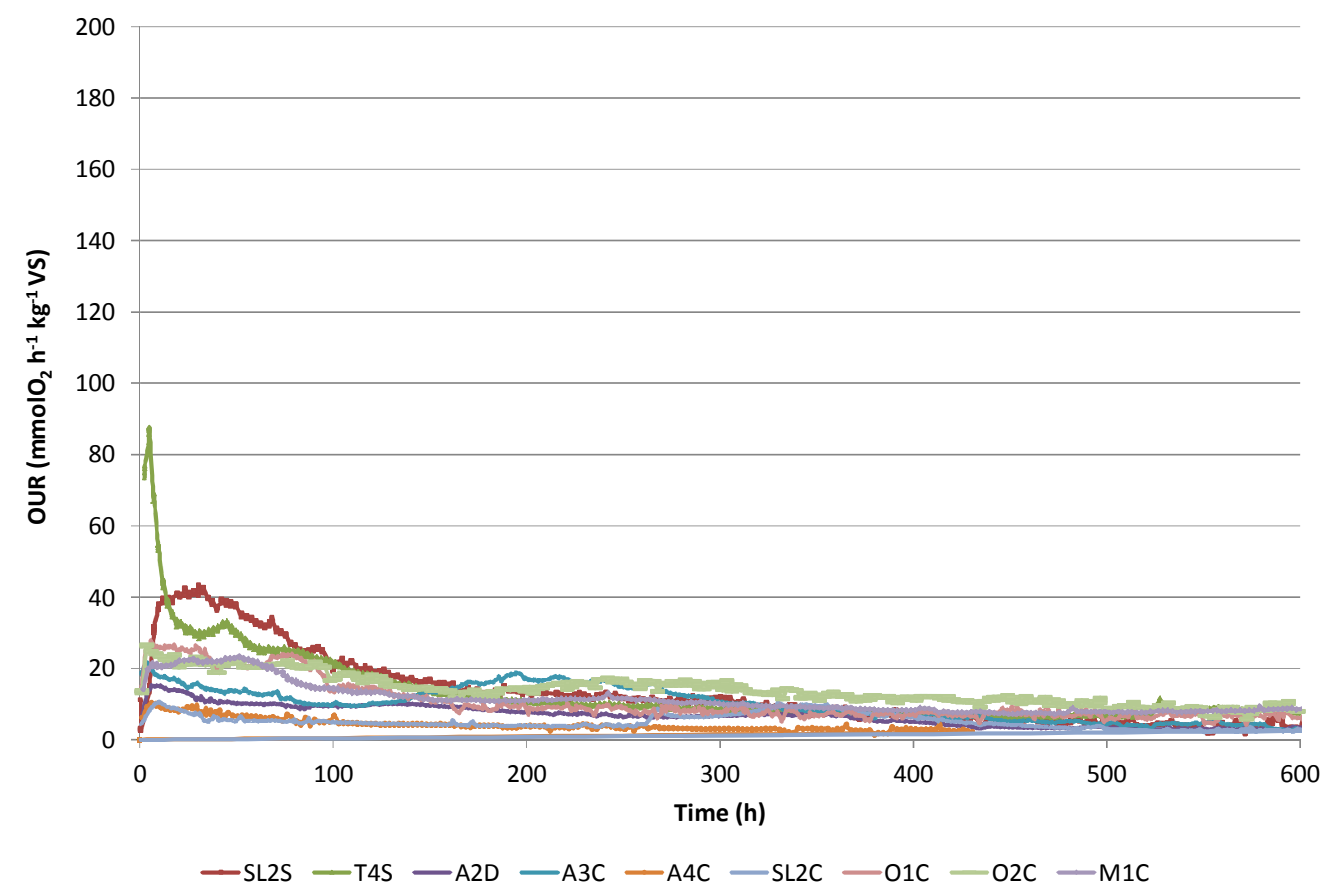

(b)

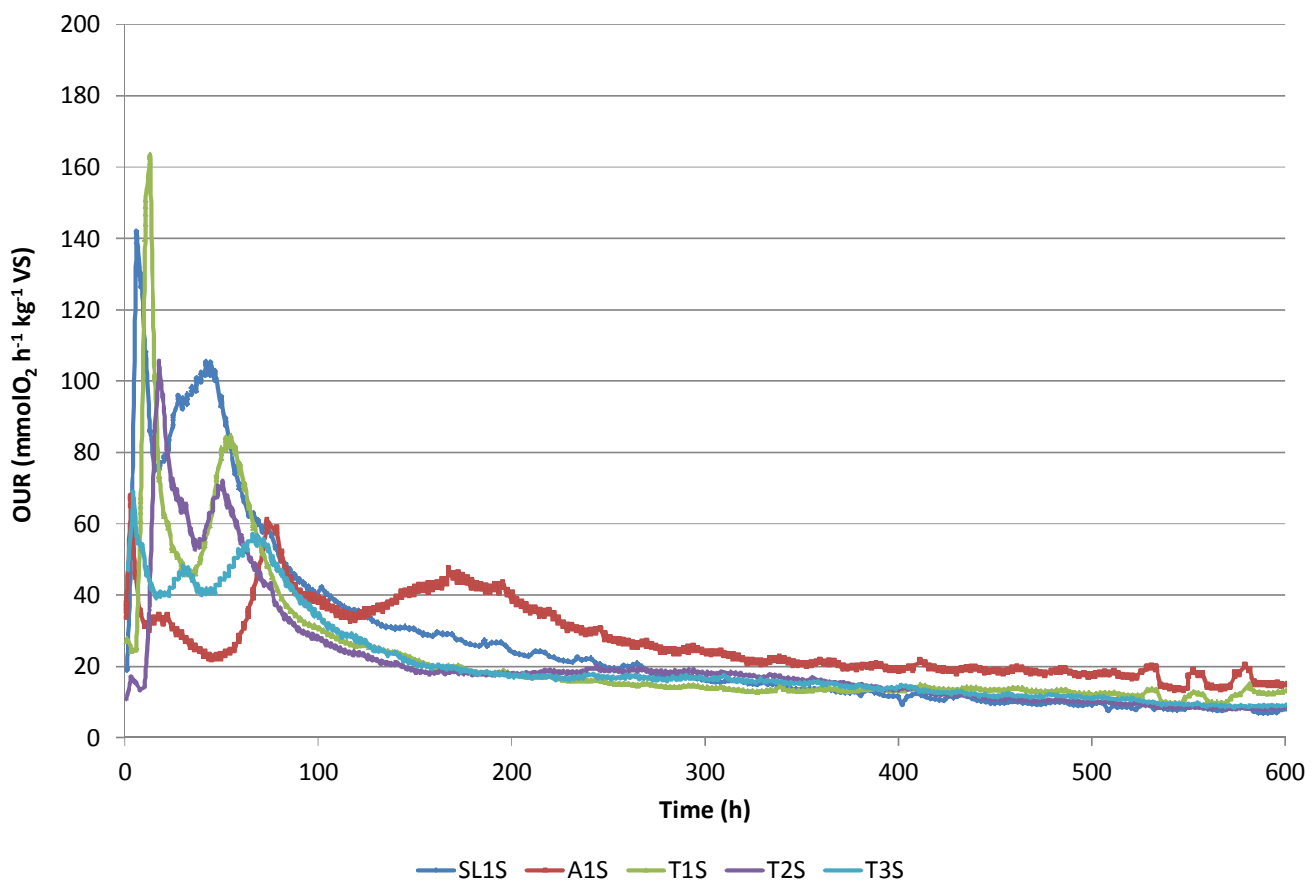


Fig. 4.

(a)

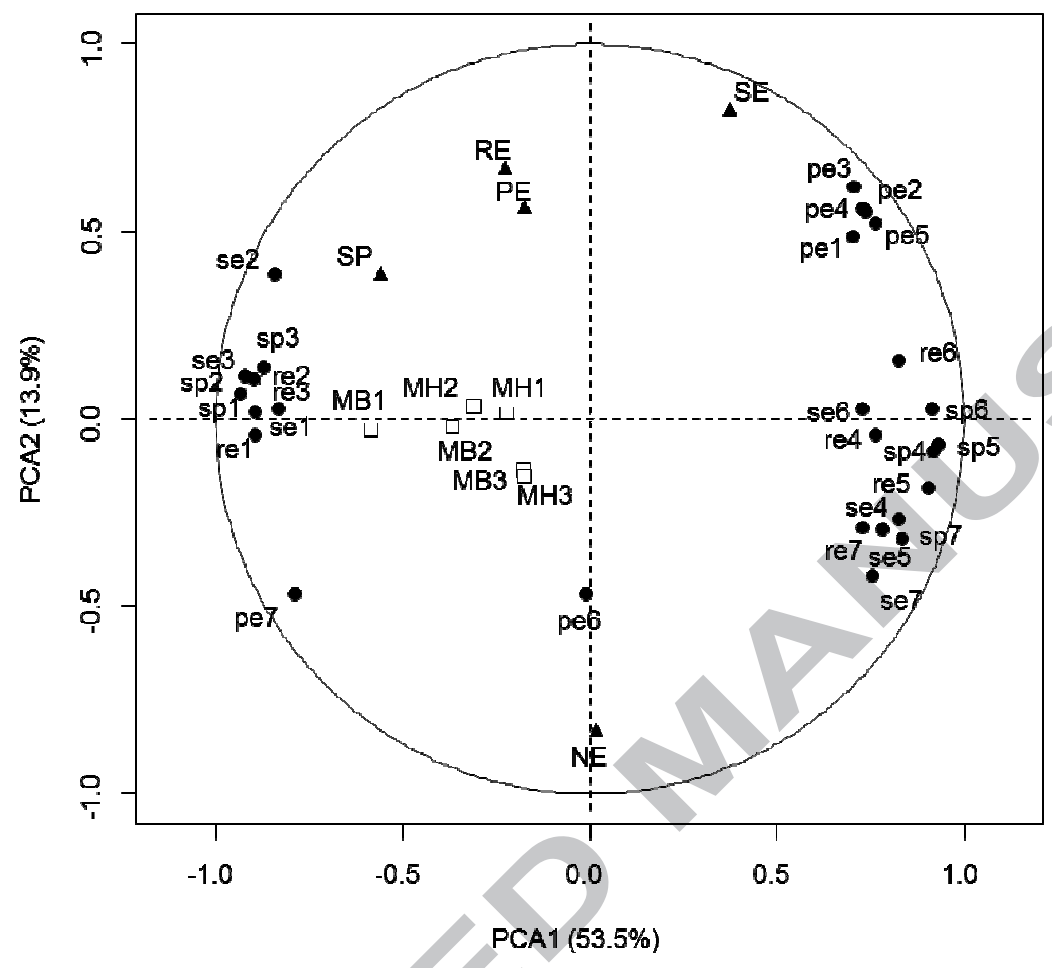

(b)

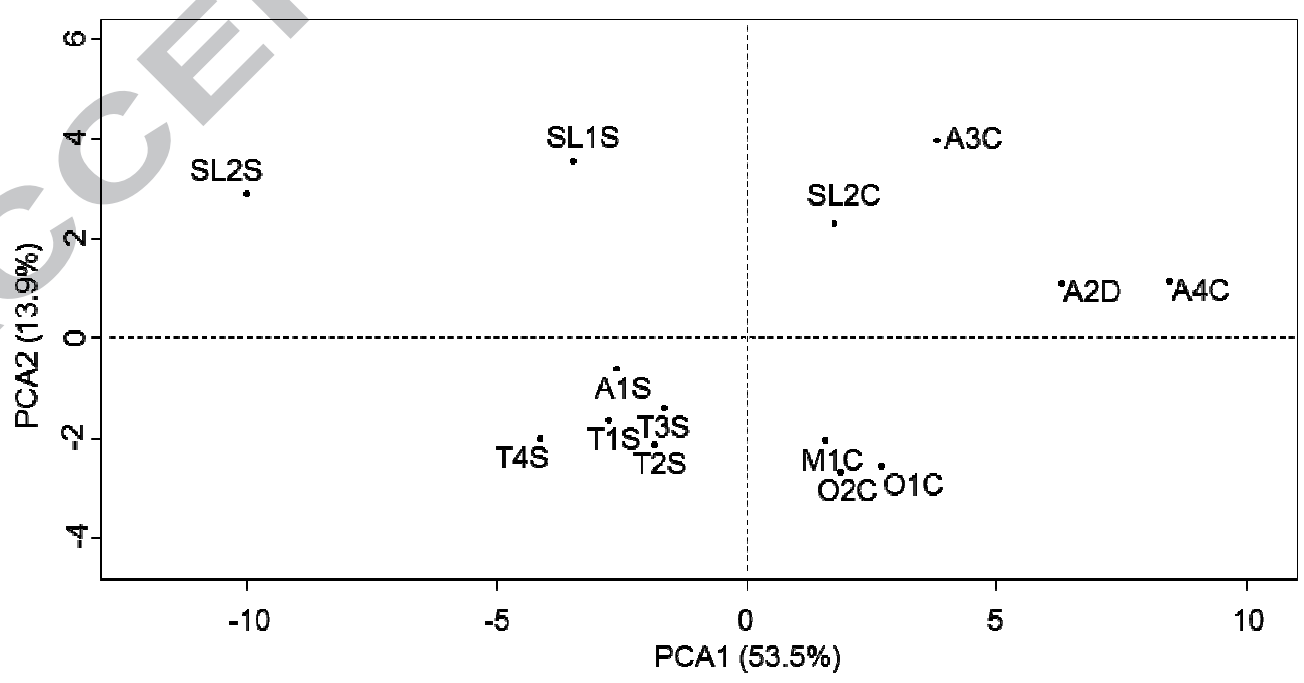




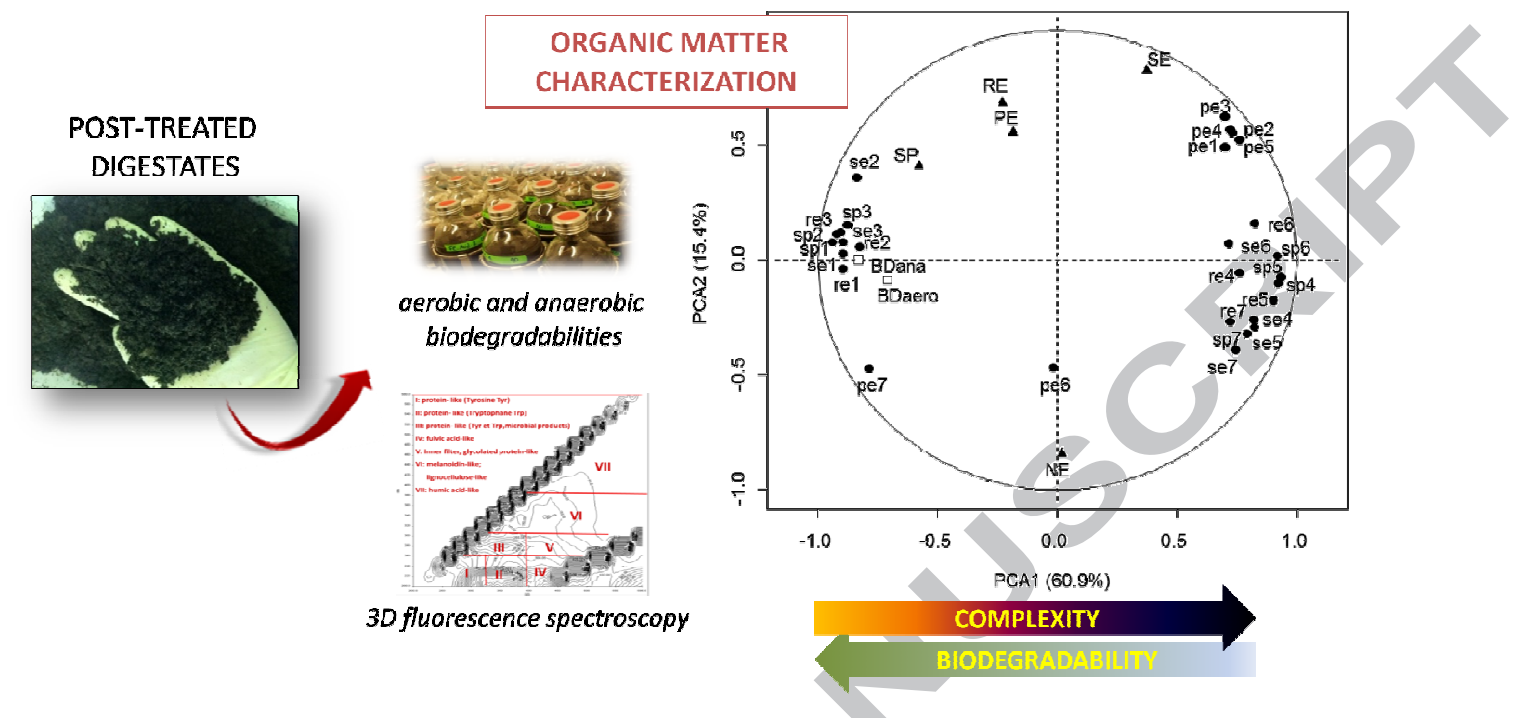

Graphical abstract 


\section{Highlights}

- Aerobic and anaerobic biodegradabilities are linearly correlated

- Biodegradability is mostly anti-correlated with the complexity of organic matter

- Post-treatments have a significant effect on biodegradability and complexity

- Kinetics of respirometric activity present multi-peaks for certain digestates 